\title{
Representasi Perempuan dalam Aplikasi Bigo Live Streaming
}

\author{
Rella Swandari Hariwidiaswari ${ }^{1}$, Syafruddin Ritonga $^{2}$
}

\author{
${ }^{1}$ Magister Ilmu Komunikasi Universitas Prof. Dr. Moestopo (Beragama) \\ Jl. Hang Lekir 1 No. 8, Senayan, Jakarta - Indonesia \\ ${ }^{2}$ Jurusan Ilmu Komunikasi Fisipol Universitas Medan Area \\ Jl. Kolam No. 1, Medan Estate, Medan - Indonesia \\ Correspondent author: swandari.rella@gmail.com
}

\begin{abstract}
This study discusses the representation of women in achieving material satisfaction by using BIGO Live Streaming application to get the gifts provided by some spectators (spender) during the broadcast. Various attempts were made by female broadcasters to get the attention of the spender and to easily give gifts in the form of beans that can be cashed in rupiah. In addition to these cashed gifts, BIGO Live Streaming also provides rupiah bonuses to the broadcasters with high viewer ratings and also the highest revenue each month. This study focuses on account holders, who are beautiful female-faced announcers, have sexy bodies and exploit them for popularity, pursuing lifestyles, obtaining material benefits, to the benefit of gaining a wide network of friends. This research uses descriptive-qualitative method with the theory of representation on women and female commodity concept in new media. The current BIGO Live Streaming application tends to represent women making their bodies an entertaining spectacle for the benefit of certain benefits. However, in its development turned out to occur business practices with large material gains in this new media industry.

Keywords: BIGO Live, Comodity, New Media, Representation, Woman
\end{abstract}

\begin{abstract}
Abstrak
Penelitian ini membahas representasi perempuan dalam mencapai kepuasan material dengan menggunakan aplikasi BIGO Live Streaming untuk mendapatkan gifts yang diberikan oleh sebagian penonton (spender) selama siaran dilakukan. Berbagai upaya dilakukan para penyiar perempuan untuk mendapatkan perhatian dari para spender dan dengan mudahnya memberikan gifts berupa beans yang dapat diuangkan dalam rupiah. Selain gifts yang dapat diuangkan, BIGO Live Streaming juga memberikan bonus-bonus rupiah kepada para penyiar dengan rating penonton dan juga pendapatan yang tertinggi setiap bulannya. Penelitian ini fokus pada pemegang akun, yakni penyiar perempuan berwajah cantik, memiliki tubuh yang seksi dan mengeksploitasinya demi popularitas, mengejar gaya hidup, mendapat keuntungan material, hingga keuntungan mendapatkan jaringan pertemanan yang luas. Penelitian ini menggunakan metode deskriptifkualitatif dengan teori representasi pada perempuan dan konsep komoditas perempuan dalam media baru. Aplikasi BIGO Live Streaming saat ini cenderung merepresentasikan perempuan menjadikan tubuhnya sebuah komoditas tontonan yang menghibur demi mendapatkan keuntungan-keuntungan tertentu. Namun, dalam perkembangannya ternyata terjadi praktik bisnis dengan keuntungan material yang besar dalam industri media baru tersebut.
\end{abstract}

Kata Kunci: BIGO Live, Komoditas, Media Baru, Perempuan, Representasi

Copyright $\odot 2018$ Ikatan Sarjana Komunikasi Indonesia. All rights reserved

\section{PENDAHULUAN}

Semakin berkembangnya teknologi informasi dan komunikasi, maka keberadaan media sosial saat ini tidak dapat dipisahkan dari kehidupan manusia (Boer 2018, Rianto 2016). Hal itu terjadi berkat manfaat dan fungsi media sosial yang semakin memudahkan para penggunanya. Tidak hanya itu, media sosial saat ini semakin banyak hadir sebagai media aktualisasi diri yang menghibur (Ritonga, dkk, 2017). Begitu juga dengan 
salah satu aplikasi interaktif yang telah hadir sejak 2016 lalu, yakni BIGO Live Streaming yang berbasis di Singapura namun kini telah memiliki kantor resmi di Indonesia. Aplikasi ini semenjak kehadirannya telah menyita banyak perhatian bagi para pengguna dan penyuka tontonan yang interaktif dan menghibur. Melalui aplikasi ini para penggunanya dapat berbagi video streaming secara langsung dengan sesama pengguna media tersebut. Di dalamnya, kita bisa menjadi penyiar (broadcaster) video streaming, ataupun hanya menjadi penonton (viewer) yang dapat berinteraksi langsung dengan para broadcaster. Menurut penjelasan dari situs resminya, Bigo Live adalah live videostreaming social network, di mana para pengguna bisa saling menunjukan dan berbagi bakat mereka di bidang musik, fashion, dan art secara langsung bersama teman dan keluarga.

Pada masyarakat tontonan (society of spectacle), perempuan berfungsi dominan sebagai pembentuk citra (image) dan tanda (sign) berbagai komoditas (misalnya salesgirl, covergirl dan modelgirl). Menurut Guy Debord, seperti dikutip Yasraf Amir Piliang dalam Hidayati (2006), masyarakat tontonan adalah masyarakat yang dalam dirinya setiap sisi kehidupan menjadi komoditas. Setiap komoditas itu menjadi — tontonan. Dalam masyarakat tontotan, tubuh wanita sebagai objek tontonan untuk menjual komoditas - atau tubuh itu sendiri sebagai suatu komoditas tontonan -mempunyai peran yang sangat sentral (Ibrahim 1998, Wiratmo 2008). Menjadikan tubuh sebagai tontonan bagi sebagian perempuan adalah jembatan atau jalan pintas untuk masuk ke dunia populer, meraih popularitas, mengejar gaya hidup, dan buat mencapai kepuasan material. Dalam kondisi ini, perempuan tanpa menyadari sesungguhnya mereka telah dikonstruksi secara sosial untuk berada di dunia marjinal yakni dunia objek, dunia citra, dan dunia komoditas.

Ketika berbicara mengenai jalan pintas bagi perempuan untuk mendapatkan popularitas, mengejar gaya hidup, dan mencapai kepuasan material, hal ini sangat dapat dirasakan terjadi didalam aplikasi media sosial interaktif yakni BIGO Live streaming. Perempuan di dalamnya, bersedia menjadi komoditas dengan cara memanfaatkan tubuh dan kecantikannya sebagai suatu tontonan bagi orang-orang yang menyaksikan live streaming dalam aplikasi ini. Dengan cara tersebut, para penyiar perempuan (broadcaster) dapat menghasilkan pendapatan (gifts) dengan mudah melalui beans yang dikirimkan oleh para spender. Beans ini sengaja dibeli oleh para spender dengan harga yang cukup mahal melalui situs resmi BIGO, hanya untuk mengirimkan hadiah-hadiah kepada broadcaster yang disukainya dengan konten-konten yang menarik.

Beans yang diterima itu juga dapat diuangkan dalam rupiah, maka cara mudah mendapatkan uang ini sangat diminati bagi para pemula yang tidak mengindahkan kaidah-kaidah mengenai siaran dengan konten positif. Beans yang diterima tersebut dapat diuangkan dengan syarat pembagian hasil kepada penyedia layanan yakni BIGO Live. Sementara itu, para perempuan yang merupakan official host dari BIGO juga mendapatkan gaji dan bonus-bonus beans apabila mereka mendapatkan viewers dan pendapatan beans tertinggi dalam jangka waktu satu bulan.

Perempuan dalam aplikasi ini seringkali dengan sengaja menyediakan konten-konten negatif dan vulgar hanya untuk mendapatkan keuntungan material tersebut. Konten-konten yang cenderung menampilkan kecantikan paras, tubuh yang seksi, serta tampilan goyangan atau bernyanyi dari para penyiar perempuan ini sering dinilai sebagai konten yang menarik oleh para penonton (viewers). Mengenai menariknya konten yang 
disiarkan oleh penyiar perempuan dalam aplikasi ini seringkali dilakukan dengan cara yang sangat tidak mendidik dan informatif. Persepsi mengenai konten yang menarik perhatian kini disalah artikan menjadi tayangan bertema seks, pornografi, dan mempertontonkan bagian tubuh yang intim. Selain itu, kelemahan dari sistem yang dimiliki BIGO Live Streaming untuk membungkam atau memblokir siaran-siaran negatif membuat semakin mewabahnya penyiar-penyiar baru yang hanya mencari keuntungan pendapatan semata.

Sementara di sisi lain, BIGO Live Streaming dalam sistemnya telah memberlakukan peraturanperaturan dalam siaran yang dilakukan para penyiarnya. Secara garis besar peraturan yang dibuat BIGO adalah jika para penyiar melakukan pelanggaran kelas A (konten negatif, pornografi, mempertontonkan bagian tubuh, dan menyuarakan kebencian/SARA) maka ganjaran yang diterima adalah banned device atau pemblokiran akun sehingga tidak dapat mempergunakan aplikasi ini dan atau pemblokiran akunnya saja namun masih dapat membuat akun baru. Atau pelanggaran kelas B (merokok, asap rokok, dan senjata api dan senjata tajam) dengan ganjaran pemblokiran akun sementara. Peraturan ini beserta laporan (report) dari para penonton dirasa sudah cukup membantu dalam usaha untuk menciptakan konten positif. Namun sekali lagi, masih terdapat celah dari sistem BIGO Live Streaming, dimana jika tayangan negatif dipertontonkan kurang dari 3 detik, maka hal ini tidak akan terdeteksi dari sistem yang dimiliki BIGO Live. Ini seringkali yang disebut 'tiga detik aman' oleh para pengguna dari aplikasi yang kini ditaksir oleh KOMINFO. (viva.co.id, 21 Mei 2018).

Kementrian Komunikasi dan Informatika (Kominfo) pada tahun 2017 lalu pernah merencanakan untuk memblokir aplikasi BIGO live streaming, karena semakin banyak laporan dan temuan bahwa aplikasi ini menyediakan konten negatif, pornografi dan vulgar dari penyiar yang tidak bertanggung jawab dan aplikasi ini bebas diakses oleh siapapun yang menggunakannya. Namun saat ini Kominfo sudah memberikan izin kepada BIGO Live, bahkan Kominfo akan menggunakan teknologi yang dimiliki BIGO untuk membantu menyaring konten negatif di aplikasi atau platform lainnya. (viva.co.id, 21 Mei 2018).

Terlepas dari sistem teknologi penyaring konten negatif yang dimiliki BIGO Live ditaksir oleh pemerintah, masih banyak celah kecacatan yang dapat ditembus oleh para pengguna aplikasi ini, dan celah ini selalu dapat digunakan bagi para penyiar yang tidak bertanggung jawab untuk mendapatkan keuntungan rupiah semata. Bukti-bukti mengenai banyaknya siaran negatif dalam aplikasi BIGO Live dapat ditemukan didalam YouTube, diunggah oleh para pengguna (viewers) yang sengaja merekam aksi dari penyiar tidak bertanggung jawab yang umumnya adalah para penyiar perempuan.

Dengan tawaran rupiah yang menguntungkan ini, para penyiar perempuan dapat melakukan apa saja, baik yang di inginkan (request) oleh para viewers ataupun menayangkan siaran yang dengan sengaja ia perlihatkan, yakni konten negatif dan pornografi, walau ternyata kecantikan diri dan keindahan tubuhnya tereksploitasi untuk keuntungan material semata. Perempuan dalam aplikasi ini sering dijadikan simbol seks yang di komodifikasi sebagai tontonan yang menghibur oleh para pengguna aplikasi livestreaming ini. Oleh karena itu, kali ini peneliti ingin mengetahui bagaimana representasi perempuan dalam aplikasi interaktif BIGO live streaming. 


\section{KERANGKA TEORITIS}

Stuart Hall dalam buku Representation: Cultural Representation and Signifying Practicemengemukakan adanya dua sistem representasi. Pertama, mental representation, yaitu "meaning depens on the system of concept and images formedin our thoughts which can stand for or 'represent' the world, enabling us to refer to things both inside and outside our heads". Kedua, makna yang bergantung pada konstruksi sebuah set korespondensi antara peta konseptual kita, dan sebuah set tanda, bahasa, yang merepresentasikan konsep-konsep tersebut. Junaidi dalam tulisan The Body Shop: Representation and Identities, mengatakan proses yang menghubungkan 'things, concept dan sign' tersebut diberi nama representation. Begitu pula representasi perempuan dalam media massa juga akan dipengaruhi bagaimana konstruksi sosial yang melingkupinya, termasuk di dalam media online (new media). Oleh karena sebagai politik kapitalis, industri media sangat dipengaruhi berbagai hal, baik yang ada dalam organisasi media maupun ekstra media.

Istilah representasi secara lebih luas, sebenarnya mengacu pada penggambaran kelompok-kelompok dan institusi sosial. Representasi itu biasanya berhubungan dengan stereotip, tetapi tidak sekadar menyangkut hal ini. Lebih penting lagi, penggambaran itu tidak hanya berkenan dengan tampilan fisik atau tampilan yang kelihatan dari luar saja, tetapi juga yang lebih penting adalah makna yang sesungguhnya ada di balik tampilan luar tersebut. Naomi Wolf dalam bukunya The beauty Myth: How Images of beauty Are Uses Against Women mengatakan, perempuan rela menderita dengan melakukan diet dan menghabiskan banyak waktu merawat tubuhnya agar tetap langsing, indah, dan cantik. Sedangkan Gallagher (Liesbet van Zoonen, 1999) menyimpulkan; women are underrepresented in the media, in production as well as in content. Moreover, the women that do appear ini media content tend to be youngconventionally pretty, defined in relation to their husband, father, son, boss or another man, and portrayed as passive, indesicive, submissive, dependent, etc". Pernyataan tersebut sangat jelas menempatkan wanita pada posisi yang sangat inferior dibanding laki-laki yang superior.

\section{Perempuan sebagai Komoditas}

Piliang menjelaskan posisi perempuan dan tubuhnya melalui pisau analisa ekonomi politik dalam dunia komoditi. Ia memaparkan bahwa ada tiga sisi yang dapat dilihat dari tubuh perempuan ketika bicara kaitan antara (tubuh) perempuan dan ekonomi politik, yaitu ekonomi politik tubuh (political -economy of body), ekonomi politik tanda (political-economy of signs) dan ekonomi politik hasrat (political-economy of desire). Piliang melihat iklan di media, tubuh dan perempuan dengan pisau analisa ekonomi politik, ia mengkaitkannya dalam konteks kapitalisme. Kalau tadinya logika kapitalisme adalah berpijak pada produksi kebutuhan (needs) sebanyak-banyaknya dengan biaya produksi serendah mungkin, kini logika itu telah bergeser menjadi menciptakan kebutuhan (needs) melalui penciptaan citra (image) oleh biro-biro iklan. Disinilah media dan perempuan menempati posisinya dalam kapitalisme wajah baru itu (Adian, 2002). Kapitalisme bentuk baru ini menjadikan semua hal adalah tanda-tanda yang bisa dikomodifikasi, yaitu proses 
yang diasosiasikan dengan kapitalisme, dimana benda-benda, kualitas, dan tanda-tanda diubah menjadi komoditas (Barker, 2005).

Di dalam media, perempuan dan tubuhnya digunakan di dalam berbagai aktivitas ekonomi berdasarkan konstruksi sosial. Tubuh perempuan yang —di potong-potong (menjadi hanya betis, kaki, dada, punggung, pinggul, rambut, atau bibir) dan diproduksi menjadi tanda-tanda (signs) akan membentuk citra (image), makna (meaning) dan identitas (identity) mereka di dalamnya. Tanda dan citra itulah yang kemudian menjadikan perempuan sebagai obyek hasrat (desire) untuk memiliki demi mencapai kepuasan tertentu.

Prabasmoro (2004) menggambarkan bagaimana potongan tubuh perempuan hanya potongan tanda yang menjadi komoditas: Seksualitas perempuan juga dikomodifikasi. Banyak produk yang sama sekali tidak ada hubungannya dengan tubuh perempuan, menampilkan tubuh perempuan semata-mata karena tubuh perempuan merupakan nilai jual (selling point). Penggunaan tubuh dan representasi tubuh dalam media tidak saja menyangkut relasi ekonomi, tetapi juga relasi sosial dan relasi ideologi. Komodifikasi tubuh perempuan menjadi sebuah persoalan ideologi ketika penggunaan tubuhnya sebagai sebuah relasi ekonomi dilandasi dan digambarkan dalam relasi sosialnya pasif, berada dalam posisi subordinasi dan menjadi objek eksploitasi kelompok dominan saja. Bila perempuan mampu berada dalam posisi subjek yang aktif dan tidak hanya menjadi objek pasif saja, maka bisa jadi bahwa perempuan sebenarnya berkuasa atas dirinya sendiri dan berperan aktif menentukan citra, makna dan identitas dirinya. Menurut Lacan, jika perempuan menggunakan tubuhnya untuk membebaskan hasratnya dan bermain-main (jouissance) maka bisa jadi perempuan otonom berperan aktif membebaskan tubuhnya. Karenanya, bagi para pengkaji cultural studies, persoalannya bukan terletak pada benar tidaknya representasi citra perempuan dalam media tetapi pada sejauhmana perempuan mampu menjadi subjek sebagai penentu konstruksi (Barker, 2002).

\section{Konsep Ekonomi Media}

Ekonomi media sebagai kegiatan adalah aktivitas ekonomi dibidang media atau aktivitas media di masyarakat yang berpengaruh pada berbagai aktivitas lainnya, seperti ekonomi, sosial, politik dan sebagainya. Bisnis media adalah pengelolaan media secara ekonomi atau usaha bisnis dalam memenuhi kebutuhan dan keinginan baik individu, organisasi maupun masyarakat dan para pemangku kepentingan lainnya dalam rangka mencari laba (Kansong, 2010).

Secara lebih sederhana ekonomi media sebagai ilmu adalah ilmu yang membahas bagaimana perusahaan media dijalankan untuk memuaskan kebutuhan dan keinginan akan informasi dan hiburan para pemirsa dan para pemasang iklan dengan sumber daya yang tersedia. Ekonomi media juga merupakan aplikasi teori media (komunikasi) dan praktik-praktik bisnis berupa penggunaan teori komunikasi, ekonomi dan teknik manajemen dalam melakukan optimasi bisnis media. Jadi, ekonomi media adalah sinergi dari aplikasi teori komunikasi, ekonomi, manajemen, dan riset operasi.

Kita tidak bisa memahami industri media tanpa memahami kekuatan yang mempengaruhi media terlebih dahulu. Bagian-bagian dari sebuah institusi media tidak pernah bekerja di luar konteks sosial yang luas, termasuk konteks ekonomi. Ekonomi media mempelajari bagaimana industri media memanfaatkan 
sumber daya yang terbatas untuk memproduksi konten dan mendistribusikannya kepada khalayak dengan tujuan memenuhi beragam permintaan dan kebutuhan akan informasi dan hiburan. Media massa selain menjadi representasi ruang publik yang penuh dengan dinamika sosial, politik dan budaya juga menjadi kekuatan ekonomi yang mampu menghasilkan surplus. Media menjadi medium iklan utama dan karenanya menjadi penghubung dan konsumsi, antara produsen barang dan jasa dengan masyarakat.

\section{Computer Mediated Communication (CMC)}

Computer-mediated communication (CMC) ialah suatu transaksi komunikasi yang terjadi melalui penggunaan dua atau lebih komputer jaringan. Istilah tersebut secara tradisional disebut komunikasi yang terjadi melalui-dimediasi format komputer, misalnya, pesan instan, e-mail, media sosial, livestreaming platform, dan lainnya. Format tersebut diterapkan pada bentuk-bentuk lain dari interaksi berbasis teks seperti pesan teks. Penelitian CMC berfokus pada dampak sosial yang berbeda yang didukung teknologi komunikasikomputer. Banyak studi yang melibatkan internet berbasis jaringan sosial yang didukung oleh perangkat lunak sosial.

Mediation ini mengacu pada proses pertukaran pesan dimana pesan disampaikan melalui perantaraan media bentuk teknologi dari teknologi paling sederhana hingga teknologi canggih seperti komputer dan jaringan internet. Dalam perkembangannya komunikasi melalui media komputer terjadi peleburan antara komunikasi Mediation (perantara) dan Immediate (langsung). Computer Mediated Communication (CMC) mempelajari bagaimana perilaku manusia dibentuk melalui pertukaran informasi menggunakan media komputer khususnya komputer internet. Internet sebagai sebuah jaringan komputer yang memungkinkan adanya transfer data atau informasi melalui bentuk protocol transmisi menurut sistem pengalamatan global. (Nugroho, 2010)

\section{Masyarakat Tontonan}

"Commodity as Spectacle" karya Guy Debord fokus pada dua hal: (1) Pengertian tentang spectacle. (2) karakter-karakter dari spectacle itu sendiri. Guy Debord, dalam tulisannya, sebenarnya tengah mengajukan sebuah kritik penting terhadap situasi masyarakat modern di bawah kapitalisme lanjut (late capitalism). Menurut Debord, manusia modern telah menjadikan semua hal di dalam hidupnya sebagai komoditas. Dan komoditas disulap menjadi "tontonan" (spectacle), yang ditampilkan melalui dan disebar oleh media massa. Bahkan, kata Debord, tontonan adalah produksi utama dalam masyarakat kekinian. Tapi yang menarik, tontonan-tontonan tersebut bagi Debord, tidak hanya dipahami sekedar sekumpulan gambar-gambar. Melainkan yang lebih penting, tontonan itu dipahami sebagai sebuah relasi sosial di antara masyarakat modern, yang dimediasi oleh citra. Debord menulis: "The spectacle is not a collection of image, but a social relation among people, mediated by image" (Debord: 118, 1994).

Selain itu, bagi Debord, tontonan juga tidak bisa dipahami sebagai penyelewengan dunia visi, sebagai produk teknik dari diseminasi gambar-gambar. Ia adalah sebuah pandangan dunia yang telah menjadi aktual, diterjemahkan secara material. Ia adalah visi dunia yang telah diobjektifkan. Saat realitas dimasukkan ke dalam 
gambar-gambar dan kemudian menjadi tontonan, maka kehidupan riil masyarakat modern mengalami kekaburan. Karena celakanya, realitas dianggap muncul dari tontonan. Dan tontonan adalah yang nyata. Tontonan selalu dihadirkan sebagai hal yang mengasyikkan dan spektakuler serta memberikan kepaduan yang positif bagi masyarakat modern. Inilah barangkali yang menjadi karakteristik penting dari spectacle. Spectacle penuh dengan konstruksi dan penipuan-penipuan. Padahal kata Debord, dalam kekacauan realitas—karena tumpang tindih dengan tontonan - "kebenaran" hanyalah momen dari kepalsuan-kepalsuan.

Karakteristik lain dari spectacle, adalah kecenderungannya yang selalu mengulang-ngulang fakta yang sederhana, yang sebenarnya sudah 'selesai', menjadi tontonan yang terus disebar di media massa, tak ada habis-habisnya. Sehingga dalam masyarakat tontonan yang digiring oleh kepentingan ekonomi yang kapitalistik semacam ini, kata Debord, definisi dari seluruh kesadaran manusia modern mengalami pergeseran, yang mulanya hanya mengenal concept of being dan having, menjadi concept of appearing. Dimana manusia modern diharuskan untuk memperhatikan citra, rasa gengsi dan tampilan yang wah dalam mengkonsumsi barang-barang, bukan semata karena kegunaannya.

\section{METODE PENELITIAN}

Metode penelitian yang digunakan ialah deskriptif-kualitatif. Metode ini dipilih karena kemampuannya menguak informasi yang tersembunyi, sehingga dapat memberikan informasi yang lebih rinci dan mendalam dibanding metode kuantitatif. Bodgan dan Taylor mengatakan, metode kualitatif sebagai prosedur penelitian yang menghasilkan data deskriptif berupa kata-kata tertulis atau lisan dari orang-orang dan perilaku yang dapat diamati (Moleong 2007; Mulyana 2001). Objek penelitian diambil secara purposive karena peneliti tidak bertujuan untuk menggeneralisasikan temuan penelitian. Dalam hal ini, sumber data penelitian yakni aplikasi live streaming BIGO Live dan hasil wawancara mendalam. Objek kajian utama adalah perempuan (broadcaster) yang menjadi penyedia tontonan (live).

\section{HASIL PENELITIAN}

Media massa seringkali hanya dipandang sebagai institusi sosial, politik, dan budaya belaka. Akan tetapi, perkembangan dewasa ini memperlihatkan media tidak lagi dilihat sematamata sebagai institusi sosial dan politik, melainkan juga sebagai institusi ekonomi. Fakta menunjukkan bahwa media telah tumbuh bukan saja sebagai alat penyampai pesan-pesan sosial, politik dan budaya, tetapi juga sebagai perusahaan yang menekankan keuntungan ekonomi. Begitu juga dengan media sosial saat ini yakni, BIGO Live Streaming yang berkembang pesat sebagai media baru yang bekerja pada ranah sosial, politik, dan ekonomi.

Salah satu sifat dasar manusia adalah kebutuhan eksistensi dan aktualisasi diri, sifat inilah yang mendorong timbulnya kebutuhan untuk berkomunikasi dengan orang lain, mencari informasi serta menyebarkan informasi tersebut guna memperkuataktualisasi dirinya. Begitu pula dalam perkembangan teknologi komunikasi saat ini, dengan adanya media sosial yang menyediakan platform atau lahan untuk 
memberikan fasilitas pemenuhan kebutuhan seringkali digunakan oleh masyarakat dan menjadi tren. Termasuk dengan adanya aplikasi interaktif live streaming BIGO Live, yang memang dibuat untuk memenuhi kebutuhan eksistensi, aktualisasi diri, dan bahkan kebutuhan ekonomi dari para penggunanya.

Terlihat bahwa pada awalnya, para user menggunakan Bigo Live untuk menambah teman, mencari pasangan, berdiskusi tentang topik tertentu, bersenang-senang, atau pun untuk membantu meningkatkan penjualan barang dagangan (promosi). Ketika melakukan siaran, kita tidak perlu untuk menyusun secara rinci akan apa yang ingin kita tayangkan, penyiar hanya perlu tampil dan membiarkan topik pembicaraan mengalir begitu saja. Dari beberapa informan yang diwawancarai, banyak diantaranya menggunakan aplikasi live streaming ini untuk menampilkan aktivitas sehari-hari, bermain game, berdiskusi, menari, bernyanyi, hingga mencari eksistensi dan keuntungan material. Dalam perkembangannya, BIGO Live saat ini banyak digunakan oleh para penyiar yang mengkonsepkan siarannya, mulai dari latar siaran (background), konten siaran yang menarik, sampai pemilihan pakaian yang digunakan pada saat siaran berlangsung.

Untuk dapat menarik banyak penonton pun dapat dilakukan dengan cara mengadakan sebuah kuis interaktif, memilih topik yang menarik perhatian, bernyanyi, menari serta menggunakan pakaian-pakaian yang minim. Dengan seorang penyiar perempuan menggunakan pakaian yang minim seperti tanktop maupun bajubaju yang terbuka, biasanya dapat mempermudah mereka untuk mendapatkan lebih banyak penonton dan hadiah, karena memang masih banyak penikmat siaran di BIGO Live, terutama pengguna laki-laki, yang menyukai hal-hal tersebut. Sesuai dengan pernyataan dari salah satu informan, bernama SB, berusia 21 tahun. "Kalau pakai baju yang biasa saja memang pasti sedikit yang nonton, jadi harus pakai yang minim dan dandan agar terlihat lebih cantik."

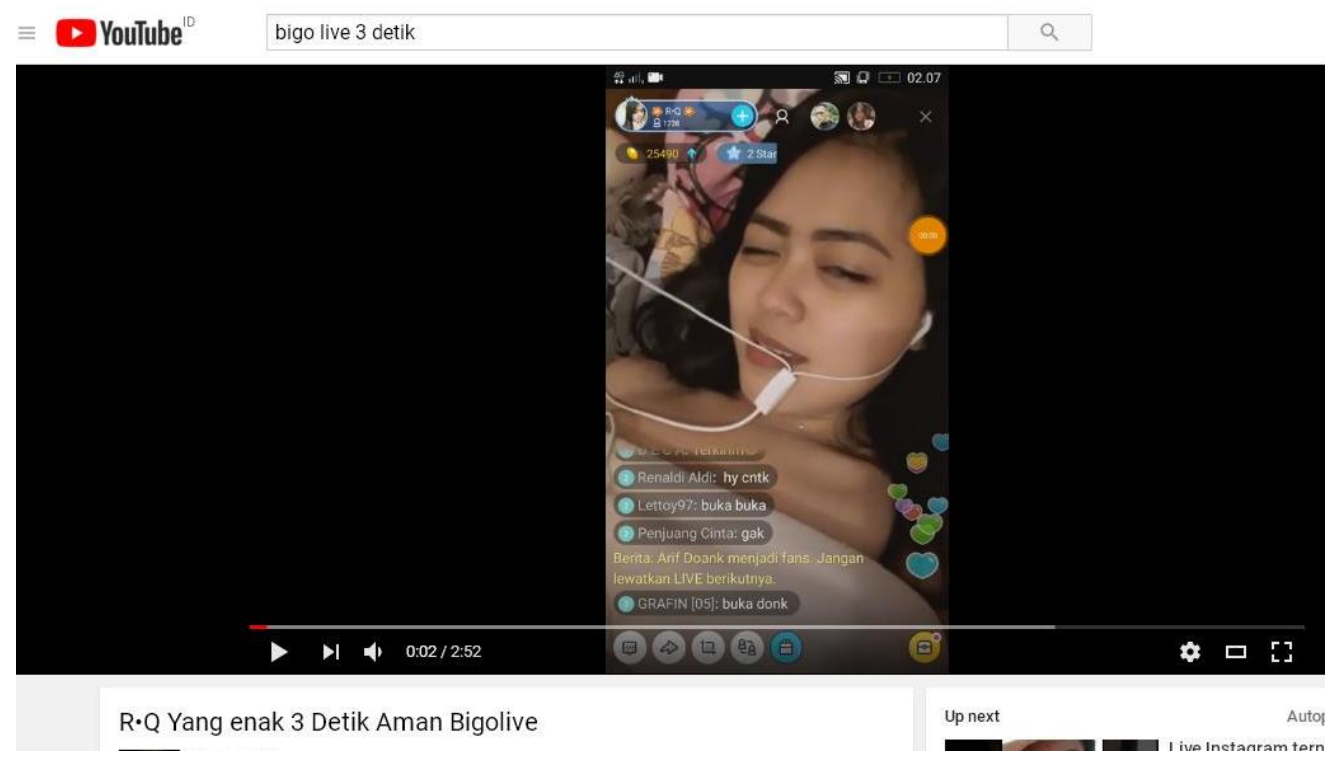

Gambar 1. "Tiga detik aman”. Sumber: youtube.com keyword: bigo live 3 detik

Bisnis dalam ranah live streaming saat ini tidak kalah menguntungkan dibandingkan dengan mediamedia massa konvensional seperti TV, radio. BIGO Live kini telah menjadi salah satu ekonomi media atau media yang dipergunakan oleh para aktor-aktrisnya sebagai lahan untuk mencari kepuasan tertentu, yakni 
keuntungan material, aktualisasi diri dan eksistensi. Terutama bagi para perempuan yang dalam aplikasi BIGO Live ini seringkali memanfaatkan identitas "perempuannya" sebagai alat untuk mencari rupiah. Banyak perempuan (broadcaster) yang sengaja mempertontonkan keindahan tubuhnya, serta bagian-bagian yang cukup intim untuk menarik perhatian kepada para penonton (spender) yang bersedia memberikannya gifts berupa beans yang didapat dari pembelian diamond di situs resmi BIGO Live. Walaupun di sisi lain, tidak ada batasan bagi siapapun baik yang mempunyai hadiah ataupun yang tidak, untuk dapat melihat para penyiar perempuan ini sedang melangsungkan siaran.

Perempuan kebanyakan diantaranya memperlihatkan tarian-tarian yang cukup erotis disertai dengan lagu-lagu sebagai latar suara agar semakin menarik perhatian para viewers. Dengan banyaknya penonton yang berada di ruang siarannya, maka siaran tersebut akan naik ke urutan siaran teratas dengan jumlah penonton yang banyak. Dari hal inilah dapat dilihat bahwa semakin berani penyiar perempuan memperlihatkan keindahan tubuhnya, maka semakin banyak penonton dan juga para spender yang dengan sukarela memberikan hadiah-hadiah dengan tawaran penyiar ini untuk memperlihatkan bagian-bagian tubuh yang vital sekalipun.

Hadiah yang diberikan oleh para spender ini didapat berupa beans oleh penyiar dan dapat diuangkan ke dalam satuan rupiah kepada pihak BIGO Live. Walaupun ada pemotongan hasil yang cukup besar, tidak menutup bisnis yang melibatkan nominal ekonomi yang cukup besar ini. Tidak sedikit para spender yang memiliki banyak uang ini, sengaja mendukung para perempuan yang memiliki paras cantik dan tubuh yang indah untuk "dijual" dengan mempergunakan tubuhnya sebagai alat menjaring banyaknya spender lain yang secara tidak sadar sudah menghabiskan banyak uangnya untuk membeli diamonds.

Sebenarnya, ada bisnis yang lebih besar dibalik bisnis menjual tontonan dan tubuh perempuan sebagai komoditas tontonan, yakni bisnis yang dipergunakan oleh para penguasa siaran, yaitu perusahaan BIGO Live Streaming yang menyediakan platform dengan segala kemajuan teknologi komunikasi. Para aktor-aktor di dalamnya, seperti penyiar, penonton, maupun spender, seolah-olah menikmati kenyamanan menonton berbagai macam hal, dan menganggap aplikasi ini sebagai sarana untuk menyalurkan hobi dan minat masingmasing pengguna. Namun, keuntungan yang dimiliki oleh perusahaan ini ternyata jauh lebih besar daripada yang dapat dilihat. Ditambah lagi, untuk dapat menukarkan keuntungan dalam virtual account BIGO Livenya, para perempuan ini harus ikut serta dalam salah satu manajemen resmi di bawah naungan BIGO Live, yang digunakan sebagai perantara antara perusahaan dan penyiar dalam hal pemberian gaji dan pendapatan, hingga pengawasan rating dari penyiar juga pelaksanaan tugas-tugas bulanan untuk dapat mencairkan pendapatannya dalam rupiah. BIGO Live mendapatkan keuntungan dari sistem bagi hasil pendapatan, misalnya, per 10.000 beans yang dimiliki hanya dapat ditukarkan sejumlah 3000 diamonds atau setara kurang dari 700.000 apabila ditukarkan dalam rupiah, ini belum termasuk potongan dari manajemen dan pajak. Sedangkan untuk membeli 3000 diamonds untuk dihadiahkan kepada penyiar, diperlukan kurang lebih 1 juta rupiah.

Sesuai data yang didapat, para penyiar dalam aplikasi ini mendapatkan kesempatan untuk mendapat intensif bulanan, dengan syarat harus siaran selama 2 jam sehari dan memiliki pendapatan sekitar 20.000- 
30.000 beans setiap bulannya sehingga pendapatan tetap perbulannya dapat diberikan kepadanya dan apabila beans yang didapat berlebih maka dapat ditukarkan dalam rupiah. Walau beberapa diantara manajemen resmi ini menentukan ketentuan dan syarat bagi official broadcaster yang berbeda-beda, namun pergerakan uang dalam aplikasi ini merupakan bisnis yang menguntungkan bagi beberapa orang yang menyukai pekerjaan tidak tetap. "Sebulan paling minim dapat delapan juta-an lah kalau rajin siaran. Itu juga sudah include insentif dua juta. Cuma modal cantik, kamera bagus, dan internet aja asal sanggup menarik spender, tenang aku setiap bulannya.", ungkap Rina salah satu penyiar dengan rata-rata 300 viewers setiap siaran dan memiliki spender tetap.

Terkait dengan siaran-siaran yang berbau pornografi, BIGO Live sebelumnya telah ditindak lanjuti oleh Kementerian Komunikasi dan Informasi terkait konten-konten siaran negatif dengan cara pemblokiran platform pada 2017. Namun, hal ini tidak berlaku lagi ketika BIGO Live telah resmi mendirikan kantor di Jakarta pada awal Januari 2018. Kelemahan sistem banned atau blockir yang dimiliki BIGO Live juga sering dimanfaatkan oleh para penyiar nakal dalam usaha menaikan rating siaran dan pendapatan beans. Kelemahan sistem dapat teridentifikasi ketika tayangan vulgar dipertontonkan kurang dari tiga detik, karena dalam jarak waktu tiga detik ini sistem banned dari BIGO Live tidak dapat mendeteksi adanya pelanggaran. Terlebih lagi, ketika siaran dilakukan dengan format multi-guest, yakni siaran yang dilakukan dengan delapan orang tamu dan satu orang penyiar utama. Di dalam format siaran ini, kelemahan sistem dalam mendeteksi pelanggaran lebih minim, walaupun banyak juga di report atau dilaporkan oleh penonton, butuh beberapa waktu untuk sistem dapat mendeteksinya sehingga lemahnya sistem ini seringkali dimanfaatkan oleh beberapa oknum untuk mendapatkan keuntungan material.

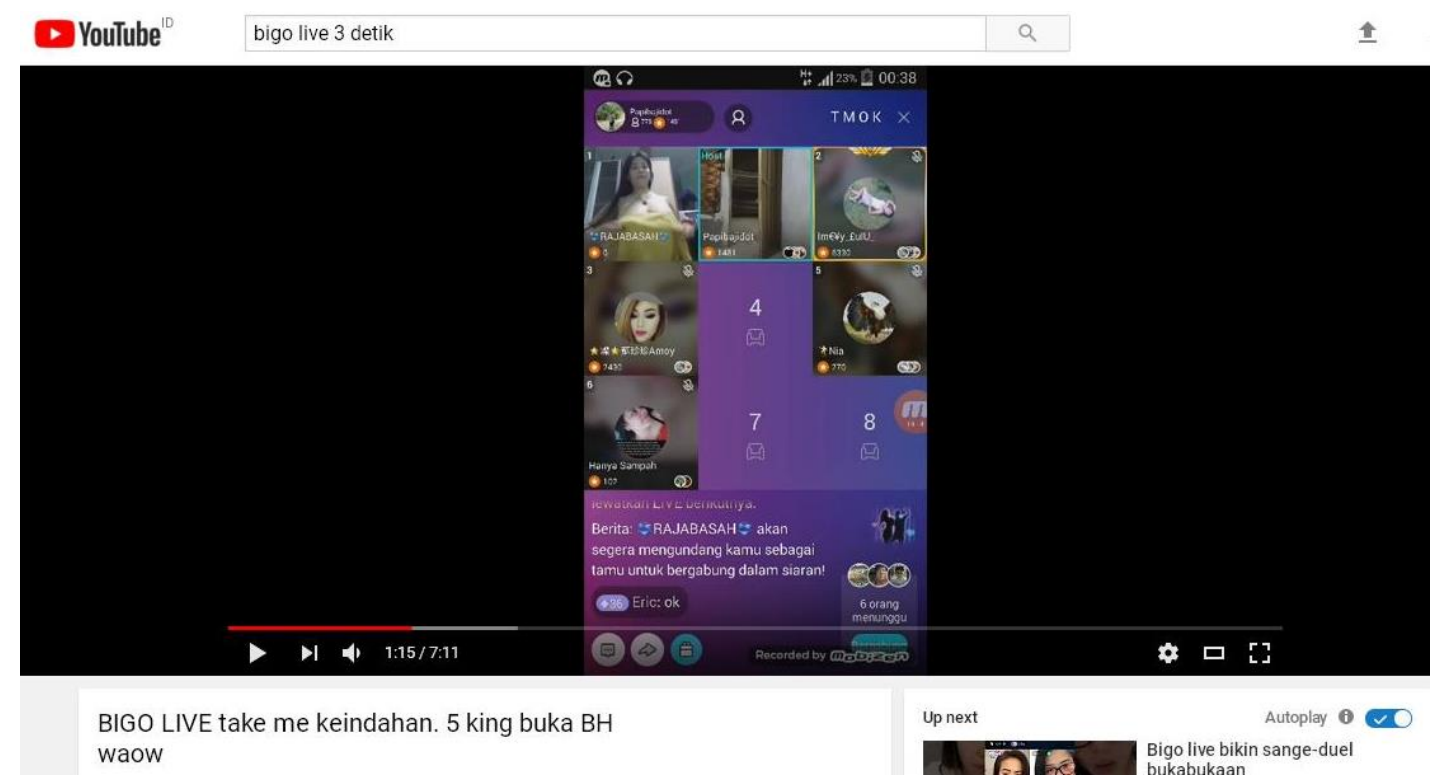

Gambar 2. Pose "menantang" penyiar. Sumber: youtube.com | Format siaran multi-guest

Sesuai dengan prinsip ekonomi media, dimana industri media memanfaatkan sumber daya yang terbatas untuk memproduksi konten dan mendistribusikannya kepada khalayak dengan tujuan memenuhi beragam permintaan dan kebutuhan akan informasi dan hiburan, maka di dalam industri media sosial live 
streaming BIGO Live juga memanfaatkan sosok perempuan dalam usahanya untuk memenuhi surplus ekonomi media itu sendiri dengan dalih memenuhi permintaan dan kebutuhan dari penonton yang menggunakan aplikasi ini. Hal ini dilandasi oleh banyaknya penonton pada siaran-siaran yang menampilkan tubuh, kecantikan, dan tayangan pornografi yang dilakukan. Perputaran bisnis yang sebenarnya terjadi ketika para spender ini menghabiskan uangnya untuk membeli diamonds dan diberikan kepada penyiar perempuan. Memang seolah-olah para penyiar ini mendapat keuntungan material dan eksistensi, tapi dibalik itu ia tidak menyadari bahwa sifat perempuannya sudah dijadikan komoditas tayangan yang menguntungkan segelintir pihak. Terlebih lagi hal ini tidak hanya berkembang di Indonesia, namun banyak juga di negara lain seperti Singapura, Malaysia, Thailand, China, dan Russia.

Temuan lainnya berdasarkan wawancara yang dilakukan kepada beberapa narasumber yakni keuntngan lainnya yang didapat di luar platform BIGO Live, bahwa mereka mendapatkan link untuk melakukan prostitusi online seperti menyediakan tayangan video call sex dalam platform lain seperti live instagram, whatsapp dan line, atau bahkan mereka menjajakan dirinya kepada penonton dari BIGO Live melalui jaringan pribadi dan kemudian bertemu untuk membicarakan tawaran-tawaran berbasis prostitusi nyata. Tidak sedikit yang menawarkan diri pada siaran di BIGO Live untuk kemudian melakukan bisnis prostitusi karena banyaknya laki-laki yang memang mencari pasangan lawan jenis dalam BIGO Live streaming ini.

\section{KESIMPULAN}

Semakin berkembangnya teknologi informasi dan komunikasi, semakin banyak membantu para penggunanya untuk dapat melakukan apapun, kapanpun, dan dimanapun sesuai dengan keinginan dan minatnya, termasuk dalam memilih platform untuk hiburan. BIGO Live hadir sebagai sarana untuk memenuhi kebutuhan tontonan dari penggunanya sekaligus menyediakan sarana untuk seseorang dapat turut menyiarkan hal-hal yang dirasa menarik untuk dipertunjukkan. Namun, pergeseran anggapan berubah menjadi kepada halhal yang negatif dan cenderung berbau pornografi seiring dengan minat penonton lebih mengarah kepada penyiar perempuan cantik bertubuh seksi dan menampilkan tarian-tarian bahkan bagian tubuh yang vital. Awalnya, hal ini dianggap sebagai usaha bagi perempuan untuk mendapatkan eksistensi, mengejar gaya hidup, perluasan jejaring sosial dan keuntungan material belaka.

Seiring berkembang pesatnya industri perdagangan diamonds yang menjadi uang untuk diberikan hadiah kepada para penyiar oleh para penonton (spender) maka hal ini menjadi keuntungan sendiri bagi perusahaan BIGO Live untuk menarik keuntungan dari penyiar official di bawah naungan manajemen dengan syarat tertentu dan akan diberikan gaji serta keuntungan rupiah lainnya melalui beans yang diperoleh. Padahal, keuntungan yang dimiliki perusahaan media ini lebih besar karena potongan dari ditukarnya perolehan beans ke dalam rupiah yang sangat besar. Maka perempuan dengan segala kelebihan yang dimilikinya dan menarik perhatian viewers secara tidak langsung dijadikan alat untuk memperoleh keuntungan material dalam persepektif kritis terjadi di golongan elite penguasa bisnis. 


\section{Daftar Pustaka}

Boer, Rino F. (2018). Reputation Communication of Online Companies. Jurnal Komunikasi Ikatan Sarjana Komunikasi Indonesia. Vol 3(1): 36-44.

Ibrahim, Idi Subandi dan Hanif Suranto (eds.). (1998). Wanita dan Media: Konstruksi Ideologi Gender dalam Ruang Publik OrdeBaru, Bandung: Rosdakarya, Bandung.

Kansong, Usman. (2010). Ekonomi Media, Pengantar Konsep dan Aplikasi, Jakarta: Ghalia Indonesia.

Mulyana, Dedy. (2001). Metodologi Penelitian Kualitatif. Bandung: Remaja Rosdakarya.

Debord, Guy. (1994). "Commodity as Spectacle" retrieved from http://designtheory.fiu.edu/readings/debord commodityasspectacle.pdf

Moleong, Lexy J. (2007). Metodologi Penelitian Kualitatif, Bandung: Remaja Rosdakarya

Nugroho, Agoeng. (2010). Teknologi Komunikasi, Yogyakarta: Graha Ilmu.

Rianto, Puji. (2016). Media Baru, Visi Khalayak Aktif dan Urgensi Literasi Media. Jurnal Komunikasi Ikatan Sarjana Komunikasi Indonesia, Vol. 1(1): 90-96.

Ritonga, Rajab, Endah Murwani, dan Syafruddin Ritonga. (2017). Gender Awareness of Maria Hartiningsih as Daily Kompas Reporter. Jurnal Komunikasi Ikatan Sarjana Komunikasi Indonesia. Vol 2(2): 82-91.

Wiratmo, Gifari. (2008). Representasi Perempuan dalam Majalah Wanita. Jurnal Studi Gender dan Anak. Vol 3(1): 101-119. 